medRxiv preprint doi: https://doi.org/10.1101/2021.03.10.21253173; this version posted March 12, 2021. The copyright holder for this preprint (which was not certified by peer review) is the author/funder, who has granted medRxiv a license to display the preprint in perpetuity. It is made available under a CC-BY-NC-ND 4.0 International license .

\title{
1 High household transmission of SARS-CoV-2 in the United States: living density, 2 viral load, and disproportionate impact on communities of color
}

\author{
3 Carla Cerami ${ }^{1}$, Tyler Rapp ${ }^{2}$, Feng-Chang Lin ${ }^{3}$, Kathleen Tompkins ${ }^{2}$, Christopher Basham ${ }^{2}$, Meredith S. Muller', \\ 4 Maureen Whittelsey $^{2}$, Haoming Zhang ${ }^{3}$, Srijana B. Chhetri ${ }^{2}$, Judy Smith ${ }^{2}$, Christy Litel ${ }^{2}$, Kelly Lin ${ }^{2}$, Mehal Churiwal $^{2}$, \\ 5 Salman Khan ${ }^{4}$, Faith Claman ${ }^{2}$, Rebecca Rubinstein ${ }^{3}$, Katie Mollan ${ }^{3}$, David Wohl², Lakshmanane Premkumar ${ }^{4}$, \\ 6 Jonathan J. Juliano", Jessica T. Lin ${ }^{2 *}$
}

71 Medical Research Council Unit The Gambia at the London School of Hygiene \& Tropical Medicine, The Gambia.

$8 \mathbf{2}$ Institute of Global Health and Infectious Diseases, University of North Carolina School of Medicine, Chapel Hill, NC USA

93 Gillings School of Global Public Health, University of North Carolina, Chapel Hill, NC USA

104 Department of Microbiology and Immunology, University of North Carolina School of Medicine, Chapel Hill, NC USA

$11{ }^{*}$ Corresponding author

12 Short title: High household transmission of SARS-CoV-2 in the United States

\section{ABSTRACT}

14 Background Few prospective studies of SARS-CoV-2 transmission within households have been reported from the 15 United States, where COVID-19 cases are the highest in the world and the pandemic has had disproportionate 16 impact on communities of color.

17 Methods and Findings This is a prospective observational study. Between April-October 2020, the UNC CO-HOST 18 study enrolled 102 COVID-positive persons and 213 of their household members across the Piedmont region of 19 North Carolina, including 45\% who identified as Hispanic/Latinx or non-white. Households were enrolled a median 20 of 6 days from onset of symptoms in the index case. Secondary cases within the household were detected either by 21 PCR of a nasopharyngeal (NP) swab on study day 1 and weekly nasal swabs (days $7,14,21$ ) thereafter, or based on 22 seroconversion by day 28. After excluding household contacts exposed the same time as the index case, the 23 secondary attack rate (SAR) among susceptible household contacts was $60 \%$ (106/176, 95\% $\mathrm{Cl} 53 \%-67 \%)$. The 24 majority of secondary cases were already infected at study enrollment (73/106), while 33 were observed during 25 study follow-up. Despite the potential for continuous exposure and sequential transmission over time, 93\% (84/90, 26 95\% Cl 86\%-97\%) of PCR-positive secondary cases were detected within 14 days of symptom onset in the index 27 case, while $83 \%$ were detected within 10 days. Index cases with high NP viral load $\left(>10^{\wedge} 6\right.$ viral copies/ul) at 28 enrollment were more likely to transmit virus to household contacts during the study $(\mathrm{OR} 4.9,95 \% \mathrm{Cl} 1.3-18$ $29 \mathrm{p}=0.02)$. Furthermore, NP viral load was correlated within families (ICC $=0.44,95 \% \mathrm{Cl} 0.26-0.60)$, meaning persons in 30 the same household were more likely to have similar viral loads, suggesting an inoculum effect. High household 31 living density was associated with a higher risk of secondary household transmission (OR 5.8, 95\% $\mathrm{Cl} 1.3-55)$ for 32 households with $>3$ persons occupying $<6$ rooms (SAR=91\%, 95\% Cl 71-98\%). Index cases who self-identified as 33 Hispanic/Latinx or non-white were more likely to experience a high living density and transmit virus to a household 34 member, translating into an SAR in minority households of $70 \%$, versus $52 \%$ in white households $(p=0.05)$.

35 Conclusions SARS-CoV-2 transmits early and often among household members. Risk for spread and subsequent

36 disease is elevated in high-inoculum households with limited living space. Very high infection rates due to

37 household crowding likely contribute to the increased incidence of SARS-CoV-2 infection and morbidity observed 38 among racial and ethnic minorities in the US. Quarantine for 14 days from symptom onset of the first case in the 39 household is appropriate to prevent onward transmission from the household. Ultimately, primary prevention 40 through equitable distribution of effective vaccines is of paramount importance. 
medRxiv preprint doi: https://doi.org/10.1101/2021.03.10.21253173; this version posted March 12, 2021. The copyright holder for this preprint (which was not certified by peer review) is the author/funder, who has granted medRxiv a license to display the preprint in perpetuity. It is made available under a CC-BY-NC-ND 4.0 International license .

\section{AUTHORS SUMMARY}

\section{Why was this study done?}

- Understanding the secondary attack rate and the timing of transmission of SARS-CoV-2 within households is important to determine the role of household transmission in the larger pandemic and to guide public health policies about quarantine.

- Prospective studies looking at the determinants of household transmission are sparse, particularly studies including substantial racial and ethnic minorities in the United States and studies with adequate follow-up to detect sequential transmission events.

- Identifying individuals at high risk of transmitting and acquiring SARS-CoV-2 will inform strategies for reducing transmission in the household, or reducing disease in those exposed.

\section{What did the researchers do and find?}

- Between April-November 2020, the UNC CO-HOST study enrolled 102 households across the Piedmont region of North Carolina, including $45 \%$ with an index case who identified as racial or ethnic minorities.

- Overall secondary attack rate was $60 \%$ with two-thirds of cases already infected at study enrollment.

- Despite the potential for sequential transmission in the household, the majority of secondary cases were detected within 10 days of symptom onset of the index case.

- Viral loads were correlated within families, suggesting an inoculum effect.

- High viral load in the index case was associated with a greater likelihood of household transmission.

- Spouses/partners of the COVID-positive index case and household members with obesity were at higher risk of becoming infected.

- High household living density contributed to an increased risk of household transmission.

- Racial/ethnic minorities had an increased risk of acquiring SARS-CoV-2 in their households in comparison to members of the majority (white) racial group.

\section{What do these findings mean?}

- Household transmission often occurs quickly after a household member is infected.

- High viral load increases the risk of transmission.

- High viral load cases cluster within households - suggesting high viral inoculum in the index case may put the whole household at risk for more severe disease.

- Increased household density may promote transmission within racial and ethnic minority households.

- Early at-home point-of-care testing, and ultimately vaccination, is necessary to effectively decrease household transmission. 
medRxiv preprint doi: https://doi.org/10.1101/2021.03.10.21253173; this version posted March 12, 2021. The copyright holder for this preprint (which was not certified by peer review) is the author/funder, who has granted medRxiv a license to display the preprint in perpetuity. It is made available under a CC-BY-NC-ND 4.0 International license .

\section{INTRODUCTION}

73 Since the onset of the COVID-19 pandemic, households have been a well-recognized setting for SARS-CoV-2

74 transmission. Proximity and ventilation, important determinants of person-to-person transmission [1], are difficult

75 to control in shared living spaces. For those infected and isolating at home, following guidelines to sleep in a

76 separate bedroom, use a separate bathroom, use masks, and not share items such as dishes, towels, and bedding

77 [2] may be difficult in families with young children and/or small living spaces; especially once more than one

78 household member is infected. Furthermore, since infectiousness and viral transmission peaks just before the onset

79 of symptoms [3-5], household spread can occur before anyone is aware of a potential infection, as most Americans

80 do not wear masks at home or in what they define as their family bubble.

81 Secondary household attack rates reported from China and other Asian countries early in the pandemic ranged

82 from 10-15\% [6]. This relatively low attack rate is at odds with anecdotal experience in the United States, where the

83 virus has spread unchecked. While several meta-analyses have evaluated household transmission rates, all have

84 incorporated both retrospective and prospective analyses. Prospective testing of household contacts regardless of

85 symptoms status is required to estimate the true secondary attack rate (SAR). Yet only two such studies in the US

86 have been reported. These two studies, following a total of 159 households in Utah, Wisconsin, and Tennessee,

87 have started to paint a picture of much higher SARs in US households (29 and 53\%) [7,8]. Yet, representation of

88 racial and ethnic diversity was limited (around 25\% of households), and testing was limited to 7 and 14 days of

89 follow-up, which may not capture secondary cases that result from sequential transmission within households.

90 Given the disproportionate impact of the COVID-19 epidemic on communities of color, measuring secondary

91 household attack rates in vulnerable communities is important for shaping preventive and testing strategies,

92 modeling spread, targeting high-risk populations, and assessing the length of time households should quarantine.

93 The UNC CO-HOST (COVID-19 Household Transmission Study) is the largest single-site observational household

94 cohort in the US thus far and the most ethnically and racially diverse. Covering both suburban and rural areas of

95 North Carolina, the study recruited from a testing center providing results within 24-hours that allowed for timely

96 recruitment. Weekly sampling for quantitative viral loads combined with antibody testing at one month provided an

97 extended period to evaluate transmission relative to other studies. During the time of this study, April to November

98 2020, the spike protein D614G variant was already fully penetrant in North Carolina [9]. The specific objective of

99 this study was to measure the secondary attack rate in a setting where infected individuals were asked to

100 quarantine at home and given standard guidance. Household and individual demographics as well as daily

101 symptoms and weekly viral loads were collected to identify risk factors and timing of household transmission. 
medRxiv preprint doi: https://doi.org/10.1101/2021.03.10.21253173; this version posted March 12, 2021. The copyright holder for this preprint (which was not certified by peer review) is the author/funder, who has granted medRxiv a license to display the preprint in perpetuity. It is made available under a CC-BY-NC-ND 4.0 International license .

\section{METHODS}

\section{Study Design}

104 The CO-HOST Study evaluated SARS-CoV-2 transmission in the household of individuals who tested positive and 105 quarantined at home. Here we describe the pre-planned primary analysis of the secondary attack rate and risk 106 factors associated with SARS-CoV-2 transmission in the household setting in the southern United States. Study 107 follow-up started in April 2020 and ended in November 2020.

\section{Ethics, standards and informed consent}

109 The study was approved by the Institutional Review Board at the University of North Carolina and is registered at clinicaltrials.gov (NCT04445233). All participants (or their parents/guardians) gave written, informed consent.

111 Minors over the ages of 7 provided assent.

\section{Role of the Funding source}

113 None

\section{Study setting}

115 Index cases were recruited after testing at the Respiratory Diagnostic Center at the University of North Carolina 116 School of Medicine [10]. Participants were visited between 3-4 times at their private homes using a mobile unit van 117 and returned to the Respiratory Diagnostic Center for the final study visit.

\section{Recruitment, screening and enrollment}

119 Inclusion criteria for the index cases included any patient 18 years of age or older with a positive qualitative 120 nasopharyngeal (NP) swab for SARS-CoV-2 obtained at UNC Hospitals, willingness to self-isolate at home for a 121 14-day period, willingness to participate in all required study activities for the entire 28-day duration of the study, 122 living with at least one household contact who was also willing to consent to study follow-up, and living within 123 reasonable driving distance ( $<1$ hour) suitable for home visits by the study team. Inclusion criteria for household 124 contacts of index patients included age greater than 1 year, and currently living in the same home as the index case 125 without plans to leave to live elsewhere through the end of the 28-day study.

126 Pre-screening was conducted by telephone when qualifying results of the NP swab were available. During the 127 telephone pre-screening, exclusion criteria were reviewed with the patient and the study procedures were 128 reviewed with potential study participants.

129 The overall study design is depicted in Figure S1. After consenting, all participants were visited at their homes on 130 Day 1 by a mobile clinical team. NP and nasal mid-turbinate (NMT) swabs were collected for analysis by PCR for 131 SARS-CoV-2 and blood samples were collected for serology by both a rapid antibody test and an enzyme-linked 132 immunosorbent assay (ELISA). Index cases and household contacts completed baseline questionnaires that included basic demographic and household information, abbreviated medical history, symptoms, recent travel history, and exposure to confirmed COVID-positive cases. All participants received instruction on how to perform a self-collected NMT swab. For nasal sampling, participants were instructed to insert the swab about 1-2 inches into one nostril, then swirl 5-8 times while slowly withdrawing the swab and placing it into the collection tube. In the case of 138 children. 
medRxiv preprint doi: https://doi.org/10.1101/2021.03.10.21253173; this version posted March 12, 2021. The copyright holder for this preprint (which was not certified by peer review) is the author/funder, who has granted medRxiv a license to display the preprint in perpetuity.

It is made available under a CC-BY-NC-ND 4.0 International license .

140 contacts received the questionnaire daily until no symptoms were reported for two consecutive days. Other 141 household contacts received the questionnaire daily for 21 days to monitor for symptoms that might indicate new 142 COVID-19 infection.

143 On Days 7, 14 and 21, a study staff member conducted home visits for sample collection pickup. The staff member 144 left a nasal swab on the doorstep for each participant and waited outside until everyone had completed the nasal 145 swabs. At the final study visit on Day 28 participants were asked about COVID-related care-seeking and testing and 146 underwent venipuncture for analysis of anti-SARS-CoV-2 antibodies by a rapid antibody test and by ELISA.

147 All samples collected during the study were placed into a cooler on ice immediately after collection and transported 148 to a BSL2+ laboratory within 2 hours. If a study participant was hospitalized or left the household for other reasons, 149 they were still followed until Day 28 to record outcomes, but sample collection was suspended.

\section{Laboratory analyses}

\section{qRT-PCR SARS-CoV-2 viral quantification}

Nasopharyngeal and nasal swab samples were tested using a CDC RT-qPCR protocol authorized for emergency use that consists of three unique assays: two targeting regions of the virus' nucleocapsid gene (N1, N2) and one targeting human RNase P gene (RP) (Catalog \# 2019-nCoVEUA-01, Integrated DNA Technologies) [11]. Details of assay implementation and calculation of the limit of detection are described elsewhere [12]. Briefly, samples were designated positive if all three PCRs were positive (N1 and N2 for virus, RP for adequate sampling). The viral load of each sample, in copies/uL, was extrapolated from standard curves generated for each viral assay (N1 and N2) using serial dilutions of the $\mathrm{nCoVPC}$ plasmid control ( 2 to 100,000 viral RNA copies/uL). The average copies/uL between the N1 and N2 assays was used as the final quantitative viral load. Probit analysis yielded a limit of detection (LOD) for the N1 and N2 assays of 9 and 13 copies/uL, respectively. Thus, the average LOD between the two assays, 11 copies/uL, was used as the cutoff for sample positivity. Based on the sample collection and RNA extraction volumes as well as volume of template RNA used in the RT-qPCR (5uL), the reported viral load represents the number of viral RNA copies per 5 uL of VTM or Shield sample.

\section{Serology:}

\section{Rapid Test}

The BioMedomics COVID-19 IgM/IgG Rapid Test is a point-of-care lateral flow immunoassay (LFIA) [13,14] that has been validated as a research tool [15]. Approximately 20 microliters of finger prick blood was obtained via a capillary sampler and dispensed on the sample port of the device. Two to three drops of buffer/developer solution 9 were applied and results were read after 10 minutes by trained study staff. Positive, weak positive, and negative 0 bands for IgM and IgG were recorded and a photograph was stored. A second reader reviewed the photographs 1 blinded to the field results and consensus was reached on discrepant readings.

\section{Immunoassay to detect antibodies against the receptor binding domain (RBD) of the spike protein}

Plasma samples were heat inactivated at $56^{\circ} \mathrm{C}$ for 30 minutes, then total Ig binding to the receptor binding domain (RBD) of the SARS-CoV-2 spike protein was measured using a previously described enzyme-linked immunosorbent 5 (ELISA) assay $[16,17]$. Briefly, biotinylated recombinant antigen produced in mammalian cells consisting of SARS-2 Spike 6 RBD is captured on a 96-well ELISA plate coated with streptavidin. The serum sample at 1:40 dilution is incubated with 77 the RBD-captured wells, and bound antigen detected using HRP conjugated anti-goat total (IgG, $\operatorname{lgM}$ and $\operatorname{lgA}$ ) antibody on 
medRxiv preprint doi: https://doi.org/10.1101/2021.03.10.21253173; this version posted March 12, 2021. The copyright holder for this preprint (which was not certified by peer review) is the author/funder, who has granted medRxiv a license to display the preprint in perpetuity.

It is made available under a CC-BY-NC-ND 4.0 International license .

178 a microplate reader. This in-house ELISA was previously evaluated on a large panel of well characterized samples and

179 shown to have high sensitivity and specificity for detecting SARS-CoV-2 infection [16,17].

\section{D614G genotyping}

181 A real-time PCR assay targeting a 107 bp region encompassing the D614G mutation in the SARS-CoV-2 spike protein

182 receptor binding domain associated with increased viral load [18] was designed to evaluate the prevalence of 614G

183 mutants in our study cohort. 5ul of RNA was reverse transcribed using the Invitrogen SuperScript III First-Strand

184 Synthesis System for RT-PCR kit (Thermofisher Scientific). 2.5ul cDNA was then placed in 22.5uL of qPCR master mix

185 with Roche FastStart Universal Probe Master (ROX) along with primers and probes listed in Table S1. Positive control

186 plasmids for mutant (MT) and wild-type (WT) sequences were synthesized by Genewiz (inserts listed in Table S1)

187 and used to set the appropriate Ct threshold for positivity in each run. Samples were considered WT if detected

188 only by WT probe; MT if detected only by MT probe or if detected by both MT and WT probes with MT Ct $>3$ cycles

189 lower than WT Ct; or mixed (containing both WT and MT virus) if detected by both with Ct difference of $<3$ cycles.

190 Sample size determination

191 This is a prospective observational study. The planned target enrollment was 200 households. The study was

192 stopped prior to reaching this target due to funding considerations.

\section{Study objectives and outcomes}

194 The primary objective was to evaluate the secondary household attack rate among household members of persons

195 quarantined in their home after testing positive for SARS-CoV-2.

196 The primary study endpoint was SARS-CoV-2 infection in the household contacts as determined by real-time PCR of 197 nasopharyngeal or nasal swabs for SARS-CoV-2 at any of the timepoints or evidence of seroconversion during the 198 study based on anti-SARS-CoV-2 antibody testing.

199 A secondary objective was to assess individual and household risk factors associated with SARS-CoV-2 transmission 200 in the household.

201 Data entry, handling, storage and security

202 After giving written consent, the participants were given a study identification number, which was used in all future 203 datasets for participant anonymity. Collected data were entered in real-time using electronic Case Report Forms 204 (eCRF) developed on a REDCap (Research Electronic Data Capture) database. Any data collected on paper format 205 was entered by a study staff member and then checked by the study coordinator. Daily symptom diaries were 206 entered directly into the REDCap database by the participants and were checked by study staff for completion and 207 inconsistencies. Laboratory related data were extracted directly from laboratory equipment and uploaded to the 208 database. The study was conducted in compliance with Good Clinical Practice.

\section{Statistical analysis}

210 For each household, if multiple participants were SARS-CoV-2 positive at enrollment, we defined the index case as

211 the person with the earliest onset of infection based on onset of symptoms and known date(s) of PCR test

212 positivity. If this was ambiguous and to prevent bias, then baseline antibody positivity was also used as evidence of

213 less recent infection. This resulted in index case reassignments in 11 households. Any study participant with

214 evidence of prior infection (antibody-positive with negative PCR) at enrollment was excluded from the analysis

$215(n=4)$. 
medRxiv preprint doi: https://doi.org/10.1101/2021.03.10.21253173; this version posted March 12, 2021. The copyright holder for this preprint (which was not certified by peer review) is the author/funder, who has granted medRxiv a license to display the preprint in perpetuity. It is made available under a CC-BY-NC-ND 4.0 International license .

216 We summarized demographic characteristics and underlying conditions of index cases and household contacts, as

217 well as their household demographics. Baseline characteristics that are continuous variables were dichotomized 218 (e.g. age, BMI) per standard conventions.

219 The secondary attack rate (SAR) among household contacts was calculated as the proportion of susceptible 220 household contacts with laboratory-confirmed SARS-CoV-2 infection during the 28-day follow-up period. Household 221 contacts who were COVID-positive at enrollment and reported the same COVID exposure outside the household as 222 the index case were not considered in the at-risk population as susceptible contacts. As per above, secondary cases 223 were defined as the remaining susceptible household contacts found positive for SARS-CoV-2 by PCR testing or with 224 evidence of seroconversion during the study. Household contacts were excluded from the SAR analysis if they 225 missed all follow-up study visits $(n=6)$ or were symptomatic with negative PCR testing but missing antibody data at 226 day $28(n=1)$. Among those included in the analysis, the rate of missing data was low $(<5 \%)$; thus, we did not impute 227 missing data. A 95\% Cl for the SAR was constructed using the Wilson method for a single proportion. A logistic 228 regression model with a random intercept to account for within-household variation was used to calculate the 229 race/ethnicity-specific SAR.

230 In the primary SAR analysis, all secondary cases were presumed due to household transmission (not 231 community-acquired). Sensitivity analyses were performed excluding secondary cases already infected at baseline 232 or excluding secondary cases identified at day 14 or later that may have been acquired outside the household. The 233 SAR for households was calculated as the proportion of households with at least one secondary case identified in 234 the household during the 28-day follow-up.

235 We estimated the serial interval (in days) of symptom onset between sequential SARS-CoV-2 infections in the 236 household, as well as the number of days between symptom onset of the index case and PCR positivity of 237 secondary cases in the household.

238 We determined whether nasopharyngeal SARS-CoV-2 viral loads were correlated within households (whether 239 persons in the same household were more likely to have similar NP viral loads) by the intraclass correlation 240 coefficient (ICC), which compares within versus between households variation of baseline NP viral loads. For those 241 participants who did not complete an NP swab on study day 1, we used a transformed NMT viral load to impute the 242 missing NP value. The transformation formula was derived from a linear regression equation generated from $>100$ 243 study participants with positive viral load from both NP and NMT swabs on study day 1 [12]. To determine whether 244 NP viral load in index cases was associated with secondary cases in the same household, we dichotomized the NP 245 viral load with a cutoff of $1 \times 10^{\wedge} 6$ viral copies/ul and compared the proportion of transmission events.

246 Finally, we examined other potential risk factors for secondary transmissions within the household, including 247 characteristics of index cases, household contacts, and their household environment. We presented the odds ratio 248 (OR) and corresponding $95 \% \mathrm{Cl}$ for potential risk factors using logistic regression with a random intercept to account 249 for within-household correlation. Household contacts were excluded from the risk factors analysis if they missed all 250 follow-up study visits $(n=3)$ unless they were already found to be infected at enrollment $(n=3)$. To address potential 251 misclassification, we excluded household contacts with negative PCR testing but missing antibody testing at day 28 $252(n=3)$.

253 Statistical analysis and preparation of figures were conducted using R 4.0.2 (R Core Team, Vienna, Austria), 254 GraphPad Prism (GraphPad Software INC, CA 92037, USA), and ArcGIS (Esri, Redlands, California). All hypothesis 255 tests were two-sided at a significance level of 0.05 with no adjustment for multiplicity. 


\section{7 infection. Two}

268 households were

269 excluded from analysis

270 because all household

271 contacts either had

272 evidence of prior

273 infection at baseline

274 (antibody-positive with

275 negative PCR test) or did

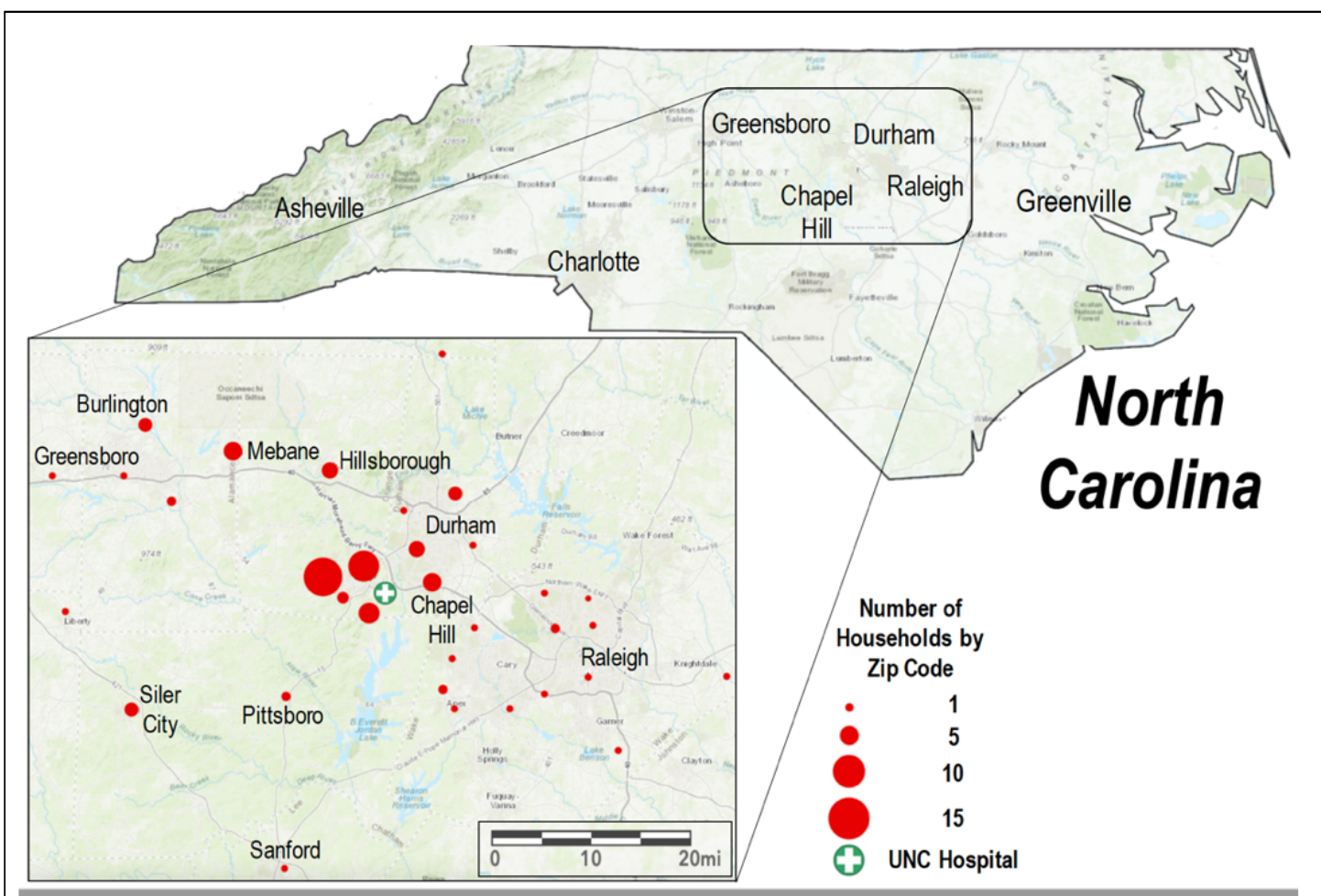

Figure 1. Geography of 100 households enrolled the UNC CO-HOST study.

276 not complete the baseline questionnaire. The remaining 100 households (median size $=3.5$ persons) were enrolled

277 a median of 6 (IQR 4-7) days after symptom onset of the designated index case. These households spanned 34 zip

278 codes across the North Carolina Piedmont Region, North Carolina, USA (Figure 1).

279 Among the 100 participating households, the index case was reassigned in 11 households. Four household contacts 280 were antibody-positive but PCR-negative at enrollment (indicating prior infection) and thus excluded from analysis.

281 One household contact without antibody data at either day 1 or day 28 was also excluded. Baseline characteristics

282 for the remaining 100 index cases and 204 household contacts (HCs) enrolled in the study are shown in Table 1.

283 Among the 100 index cases, 48 were male, 52 were female, 92 were over 18 years of age and 42 reported

284 non-white race-ethnicity. The index cases had a median viral load of 148,992 copies/ul (IQR 757-2,423,155

285 copies/ul) at the first study visit on nasopharyngeal (NP) swab. Among the 204 household contacts, $48 \%$ were male, $28652 \%$ were female, $66 \%$ were over 18 years of age and $47 \%$ reported non-white race-ethnicity. Both the index cases 287 and HCs had a similar percentage of adult participants with a Body Mass Index (BMI) over $30 \mathrm{~kg} / \mathrm{m}^{2}: 38 \%$ of index 288 cases and $32 \%$ of household contacts, consistent with the prevalence of obesity in North Carolina (34\%)[19]. A 289 significant number of adult index cases (24\%) and household contacts (19\%) had both obesity and one other 290 co-morbidity. Further description of the underlying conditions is shown in Table S2. Three index cases and three 291 household contacts (all from different households) also enrolled in a treatment study in which they were 292 randomized to receive either the oral drug EIDD-2801 (molnupiravir) or placebo (NCT04405570).

293 Household demographics are shown in Table S3. 27\% of participating households were limited to two members, 294 while $28 \%$ of households had 5 or more members. $63 \%$ were owner occupied single family homes and $42 \%$ lived in 295 homes greater than 2,000 square feet. Households with a non-white index case were larger (median household size 2964 versus $3, p=0.02$ ) and also more likely to live in a home $<2,000$ square feet ( $76 \%$ versus $43 \%, p=0.003$ ) compared 297 to households with a white index case. This led to a higher "living density" for non-white households: $41 \%$ had >3 
medRxiv preprint doi: https://doi.org/10.1101/2021.03.10.21253173; this version posted March 12, 2021. The copyright holder for this preprint (which was not certified by peer review) is the author/funder, who has granted medRxiv a license to display the preprint in perpetuity.

It is made available under a CC-BY-NC-ND 4.0 International license .

298 household members living in a home with fewer than 6 rooms, compared to $10 \%$ of white households $(p<0.001)$. In

$29944 \%$ of households, at least one household member declined to be enrolled in the study.

Table 1. Demographics of study participants

\begin{tabular}{|c|c|c|c|c|}
\hline INDIVIDUALS & Index (n) & Index (\%) & $\mathrm{HC}(\mathrm{n})$ & $\mathrm{HC}(\%)$ \\
\hline & 100 & $\%$ & 204 & $\%$ \\
\hline Male & 48 & 48.0 & 98 & 48.0 \\
\hline Female & 52 & 52.0 & 106 & 52.0 \\
\hline \multicolumn{5}{|c|}{ Race } \\
\hline American Indian/Alaskan Native & 1 & 1.0 & 1 & 0.5 \\
\hline Asian & 2 & 2.0 & 3 & 1.5 \\
\hline Black or African American & 11 & 10.0 & 18 & 8.8 \\
\hline Native Hawian or Other Pacific Islander & 0 & 0.0 & 0 & 0.0 \\
\hline White & 58 & 58.0 & 108 & 52.9 \\
\hline Other Race & 27 & 28.0 & 65 & 31.9 \\
\hline Unknown & 1 & 1.0 & 9 & 4.4 \\
\hline \multicolumn{5}{|c|}{ Ethnicity } \\
\hline Hispanic/Latinx & 28 & 28.0 & 70 & 34.3 \\
\hline Non-Hispanic/Non-Latinx & 72 & 72.0 & 132 & 64.7 \\
\hline \multicolumn{5}{|c|}{ Language } \\
\hline Spanish speaking (yes) & 15 & 15.0 & 33 & 16.2 \\
\hline Spanish speaking (no) & 85 & 85.0 & 170 & 83.3 \\
\hline \multicolumn{5}{|c|}{ Age } \\
\hline $0-12 y$ & 2 & 2.0 & 46 & 22.5 \\
\hline $13-17 y$ & 6 & 6.0 & 24 & 11.8 \\
\hline $18-24 y$ & 21 & 21.0 & 25 & 12.3 \\
\hline $25-49 y$ & 48 & 48.0 & 67 & 32.8 \\
\hline $50-64 y$ & 19 & 19.0 & 30 & 14.7 \\
\hline$>65 y$ & 4 & 4.0 & 12 & 5.9 \\
\hline \multicolumn{5}{|c|}{ Education (excluding $<18 y$ ) } \\
\hline Total Responses for Adults >18y & 88 & $\%$ & 130 & $\%$ \\
\hline High school or lower & 40 & 46.0 & 63 & 48.5 \\
\hline College degree & 25 & 28.7 & 38 & 29.2 \\
\hline Graduate degree & 23 & 26.4 & 29 & 22.3 \\
\hline \multicolumn{5}{|c|}{ Occupation (excluding $<18 y$ ) } \\
\hline Total Responses for Adults $>18 y$ & 92 & $\%$ & 134 & $\%$ \\
\hline Education & 4 & 4.3 & 6 & 4.5 \\
\hline Healthcare worker & 13 & 14.1 & 12 & 9.0 \\
\hline Retail/hospitality/other frontline worker & 26 & 28.3 & 35 & 26.1 \\
\hline Student & 7 & 7.6 & 12 & 9.0 \\
\hline White collar worker & 21 & 22.8 & 33 & 24.6 \\
\hline Other (trade and arts) & 7 & 7.6 & 6 & 4.5 \\
\hline Not working outside the home & 14 & 15.2 & 30 & 22.4 \\
\hline \multicolumn{5}{|c|}{ Co-Morbidities (excluding $<18 y$ ) } \\
\hline Diabetes & 6 & 6.5 & 12 & 9.0 \\
\hline High blood pressure & 16 & 17.4 & 30 & 22.4 \\
\hline BMI $>30$ & 35 & 38.0 & 43 & 32.1 \\
\hline BMI 25-29.9 & 24 & 26.1 & 37 & 27.6 \\
\hline BMI >30 and one or more co-morbidity & & & & \\
\hline Adults $>18 y(n=92$ index, $134 \mathrm{HC}$ ) & 22 & 23.9 & 25 & 18.7 \\
\hline Adults $>50 y(n=23$ index, $42 \mathrm{HC})$ & 8 & 34.8 & 12 & 28.6 \\
\hline
\end{tabular}

\section{Secondary attack rate among household contacts}

301 The overall secondary attack rate (SAR) among susceptible household contacts was $60 \%$ (106/176, 95\% CI 53\%-67\%)

302 (Figure 2). Of 100 households with 304 study participants (100 index cases and $204 \mathrm{HCs}$ ) included in the analysis, 30399 households completed one month follow-up. One household of 6 withdrew shortly after enrollment. No

304 households were lost to follow-up. Twenty-two of the household contacts tested positive at baseline for

305 SARS-CoV-2, but were judged to have had the same environmental exposure to SARS-CoV-2 as the index cases (for 306 example, both attended a cookout or other gathering where multiple individuals later tested COVID-positive). These 
medRxiv preprint doi: https://doi.org/10.1101/2021.03.10.21253173; this version posted March 12, 2021. The copyright holder for this preprint (which was not certified by peer review) is the author/funder, who has granted medRxiv a license to display the preprint in perpetuity.

It is made available under a CC-BY-NC-ND 4.0 International license .

307 contacts were considered to have a common exposure with the index case and were excluded from the

308 transmission analysis, leaving 176 susceptible HCs.

309 Secondary transmission cases were defined as household members who either tested positive for SARS-CoV- 2

310 either by PCR or had evidence of seroconversion by day 28. Among the 176 susceptible household contacts, 73

311 were positive for SARS-CoV-2 at baseline (plus 3 that dropped out) and were classified as secondary cases. 33

312 additional secondary cases were observed during the study follow-up. Thus, $42 \%$ of HCs were already infected at

313 the time of study enrollment, while the cumulative SAR was $60 \%$ (106/176, 95\% Cl 53\%-67\%). Among those

314 infected at enrollment, 90\% (64/71) reported having symptoms within the previous week, with a median duration

315 of 5 days of symptoms at the time of enrollment.

316 Of the 33 secondary transmission cases that were observed during the study, 25 were identified by PCR testing and

3178 were detected only because they seroconverted and were antibody positive at the day 28 visit. The majority

318 ( $n=21$ ) occurred in the first week after enrollment. Of the 5 cases detected by PCR after the first week of

319 enrollment, 4 occurred in households of 5 or more, including 2 from the same household. Of the 33 secondary

320 cases among household contacts who became infected with SARS-CoV-2 during the study, 27 (82\%) experienced

321 symptoms while $6(18 \%)$ remained asymptomatic.

322 If restricting the SAR to a more conservative definition of only those secondary cases that were observed during the 323 study (i.e. those who tested negative at baseline), the observed SAR was 32\% (33/103). If removing late secondary

324 cases that were identified at study day 14 or later, considering that these may have been acquired via later

325 community exposure rather than household transmission, the early SAR ranged between 53-57\% (depending on

326 how the 7 cases identified only by antibody-positivity are distributed).

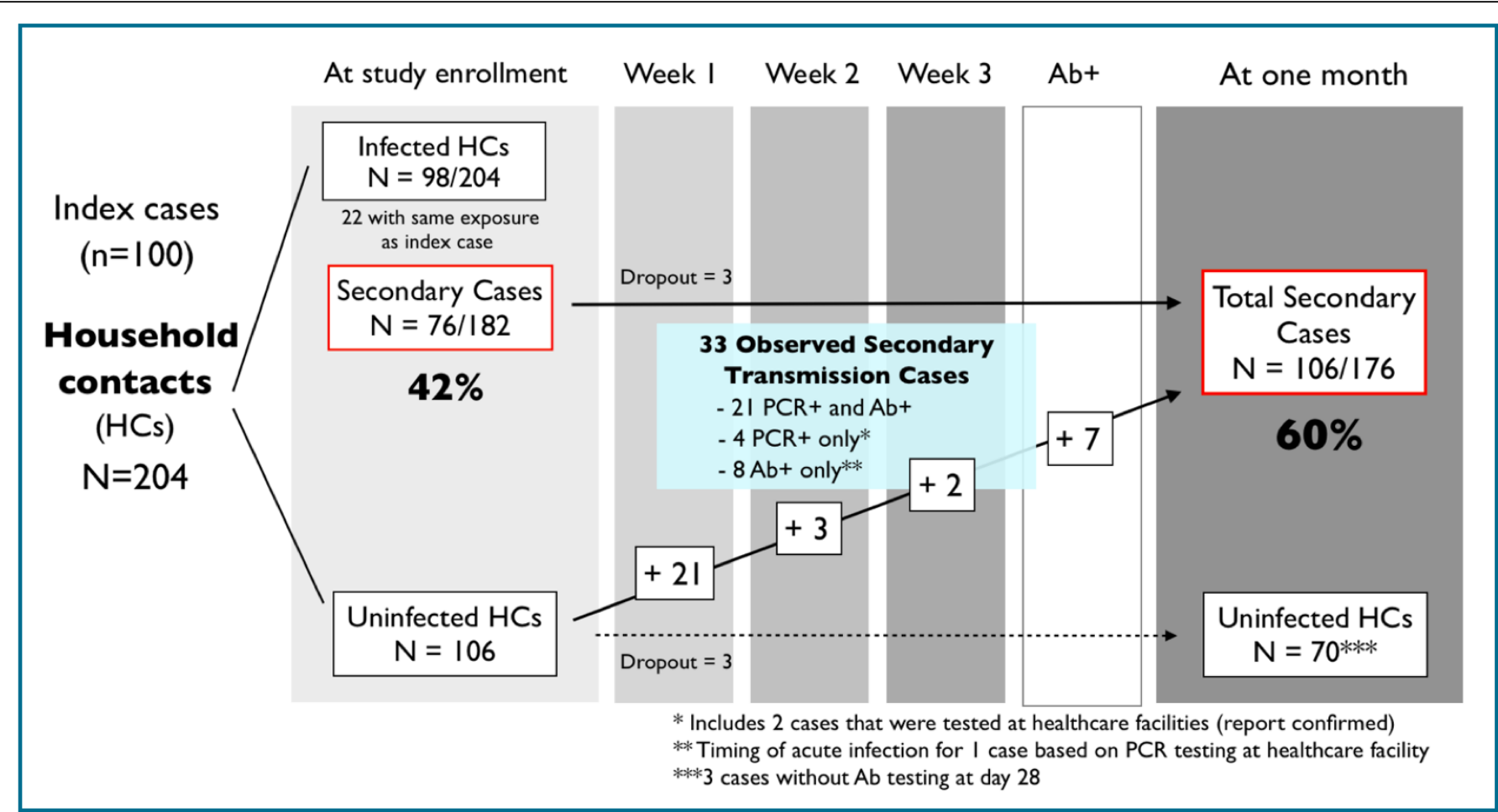

Figure 2. Secondary attack rate (SAR) among susceptible household contacts. Of 100 households included in the analysis, 99 completed one month follow-up. One household of 6 withdrew ( 3 infected at baseline). Among 182 susceptible household contacts, $42 \%$ (76/182) were already infected at the time of study enrollment and 33 additional secondary cases were observed during follow-up, resulting in an overall SAR of 60\% (106/176, 95\% Cl 53\%-67\%). 
medRxiv preprint doi: https://doi.org/10.1101/2021.03.10.21253173; this version posted March 12, 2021. The copyright holder for this preprint (which was not certified by peer review) is the author/funder, who has granted medRxiv a license to display the preprint in perpetuity. It is made available under a CC-BY-NC-ND 4.0 International license .

327 At the household level, assessing whether any secondary cases occurred within the household, SAR was even higher and skewed towards early transmission (Figure 3). Fifty three percent of susceptible households (49/92) contained at least one infected household member at enrollment besides the primary index case, rising to $70 \%$ (64/92) of households containing secondary cases one month later.

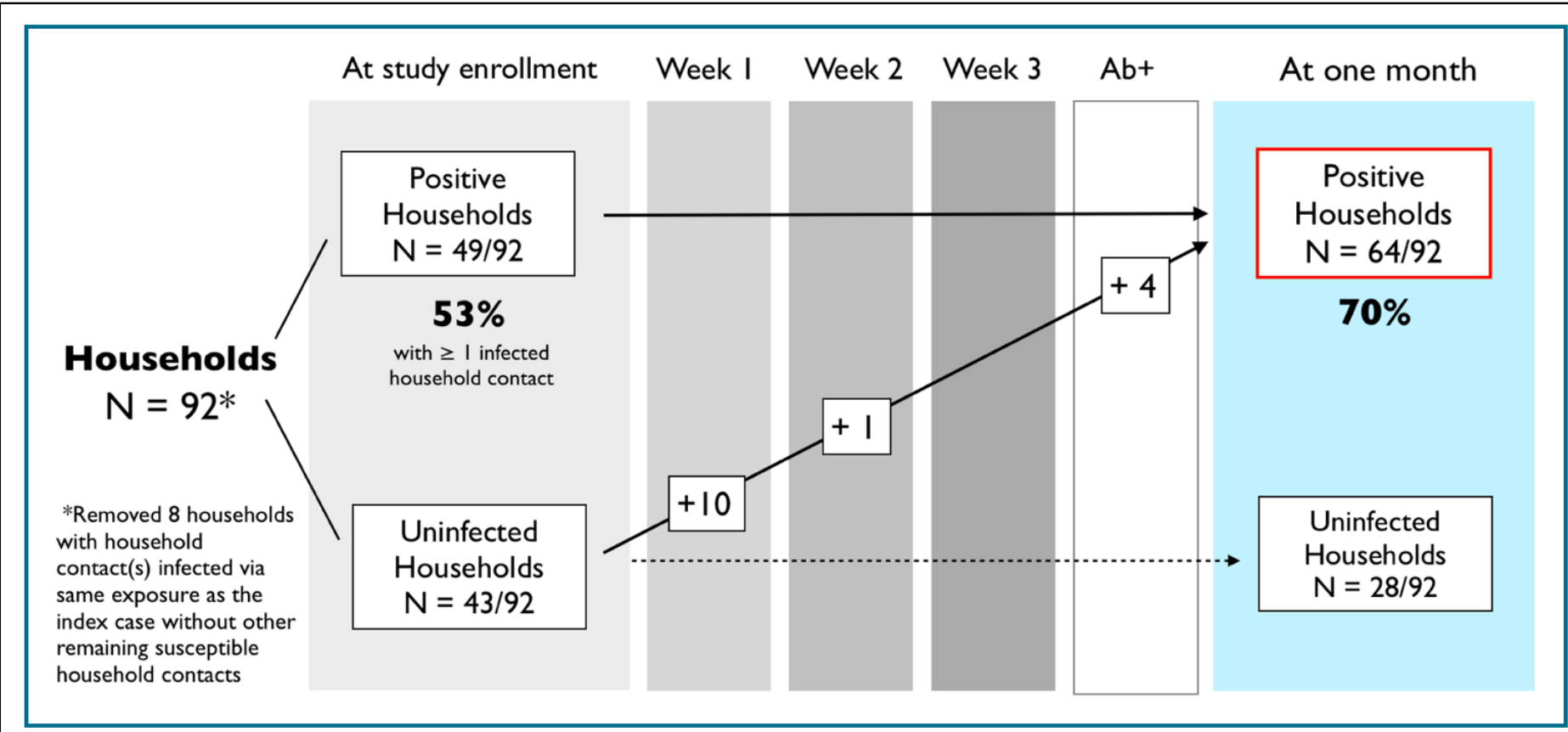

Figure 3. Secondary household attack rate. Of 92 households included in the analysis, 53\% (49/92) contained infected household contacts at enrollment, with 15 more households sustaining transmission over the next 21 days, resulting in a secondary household attacak rate of $70 \%$ (64/92).

\section{Timing of secondary cases within the household}

332 The serial interval for secondary cases in the household, based on onset of symptoms was a median of 3 days (IQR 333 1-6 days) after symptom onset in the index case and 2 days (IQR 1-4 days) from the most recent symptomatic case 334 in the household. Because over two-thirds of secondary household cases (73/106 or 69\%) were already infected at 335 enrollment and $28 \%$ of households had multiple secondary cases, we regard these as imprecise estimates.

336 However, understanding when secondary cases became PCR-positive in relation to onset of symptoms in the index 337 or other preceding case(s) is useful for informing guidelines for duration of quarantine [20]. Of the 89 PCR+ 338 secondary cases for which the index case reported symptom duration, 84\% (75/89) tested PCR-positive within 10 339 days of illness onset in the index case, while 94\% (84/89) tested PCR-positive within 14 days. When also taking into 340 account other subsequently infected household members besides the index case, 93\% (83/89) of secondary cases 341 tested PCR + within 10 days of reported symptom onset of the most recent case in the same household while $99 \%$ 342 (88/89) tested PCR-positive within 14 days. Thus, "resetting the clock" on a 14-day quarantine period based on 343 subsequent COVID+ cases in the household would have achieved incremental benefit, isolating 4 more cases during 344 the extended quarantine period. One of these was an asymptomatic infection with low viral load (402 copies/ul on 345 NMT swab) found at study day 14, while the other 3 cases ( 2 from the same household) were symptomatic prior to 346 their PCR diagnosis. 
347 Viral load within households and

348 transmission

349 SARS-CoV-2 viral burden is correlated

350 within households (Figure 4). When

351 comparing the baseline

352 nasopharyngeal viral load within

353 versus between households, viral

354 burden showed significant clustering

355 within households (ICC $=0.44,95 \% \mathrm{Cl}$

356 0.26-0.60, $p<0.001)$. Differences in

357 viral load are not attributable to

358 D614G mutation in the viral spike

359 protein that has been associated with

360 increased viral load and infectivity

361 [18], as the vast majority of isolates

362 genotyped contained the mutation.

363 Of 92 COVID-positive isolates (index

364 cases and HCs) that were successfully

365 genotyped from the first 90

366 households, 90/92 (98\%) contained

367 the $614 \mathrm{G}$ mutant, while only 2 were

368 wild-type at this locus.

369 Additionally, index cases with a high

370 NP viral load $\left(>10^{\wedge} 6\right.$ viral copies/ul) at

371 study enrollment were more likely to

372 transmit virus to their household contacts during the study (OR 4.9, 95\% Cl 1.3-18 p=0.02). The median NP viral load among index cases was 1.4 log 10

373 higher in households with new secondary cases detected during the study versus those with no transmission in the household (Figure 5). This difference

374 was even greater when restricting the analysis to index cases who were not already antibody-positive, and thus more recently infected [15,16]. This

375 association of index viral burden and transmission did not extend to secondary cases that were already present at study enrollment, likely due to a failure

376 to capture the peak viral load of the index case in these households. Other characteristics of COVID disease status of the index case - including duration of

377 symptoms and symptom severity - were not associated with secondary transmission in the household (Table 2). However, the 4 index cases that were

378 hospitalized transmitted within the household before hospitalization.

Figure 4. SARS-CoV-2 viral burden is correlated within families.

The viral load obtained at enrollment from nasopharyngeal swabs in households with multiple COVID-positive household of each member within the household. Circles shaded in gray represent values derived from a nasal mid-turbinate swab if NP sampling was not performed. Households are depicted across the $x$-axis in order of decreasing viral load. Data drawn from 98 households and 184 participants. The intraclass correlation

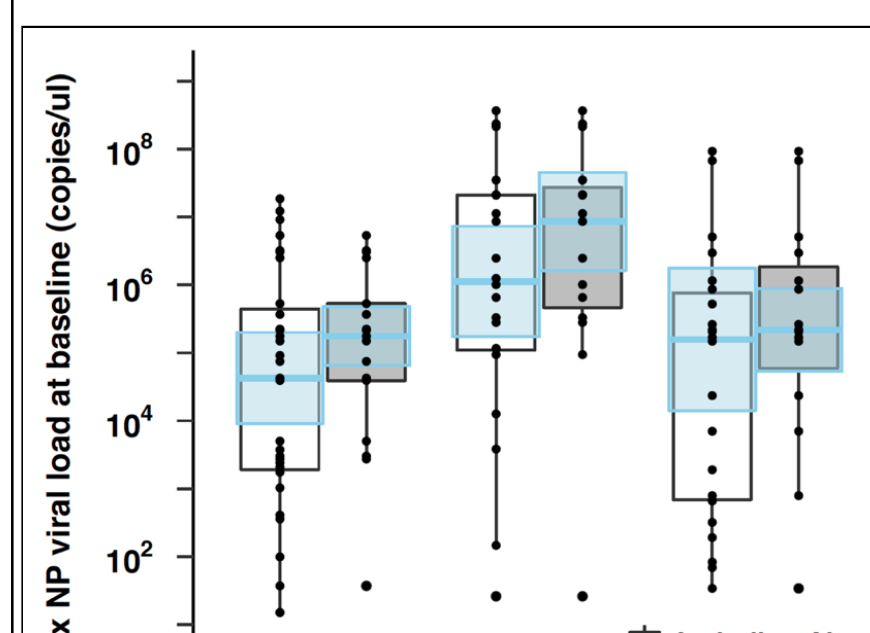

审 Including Ab+

Excluding $\mathrm{Ab}+$

Infected cases New secondary No secondary

Households

Figure 5. Association of index nasopharyngeal viral load and transmission in the household. Households with new secondary cases folllowing enrollment were more likely to have index cases with high not antibody-positive at enrollment, as a marker of more recent infection, are depicted to the right in gray. Blue overlaid boxes depict $95 \% \mathrm{Cls}$. 
medRxiv preprint doi: https://doi.org/10.1101/2021.03.10.21253173; this version posted March $12,2021$. The copyright holder for this preprint (which was not certified by peer review) is the author/funder, who has granted medRxiv a license to display the preprint in perpetuity. It is made available under a CC-BY-NC-ND 4.0 International license .

\section{Other risk factors for household}

380 transmission

381 Non-white index cases were more likely

382 to transmit virus within their household

383 (Table 2), despite there being no

384 difference in viral loads by race/ethnicity

385 (data not shown). This translates to a

386 SAR of $70 \%$ (95\% Cl 59\%-79\%) in

387 households where the index case was

388 non-white or Hispanic compared to $52 \%$

389 (95\% Cl 42\%-62\%) in white households

390 (Table 3). Among other factors, this is

391 likely attributable to household

392 crowding. A higher living density,

393 defined as greater than 3 household

394 members living in a home with fewer

395 than 6 rooms (excluding bathrooms and

396 garage), was associated with a greater

397 odds of infection (OR 5.9, 95\% Cl 1.3-27;

398 SAR 91\%, 95\% Cl 71\%-98\% in high living

399 density households) (Table 4), and a

400 greater proportion of

401 non-white/Hispanic households met this

402 definition of high living density (44\%,

403 18/41) compared to white households

$404(8 \%, 4 / 51)(p<0.001)$. Healthcare

405 workers were less likely to transmit virus

406 within the household (OR $0.2295 \% \mathrm{Cl}$

407 0.05-0.85) (Table 2).

408 Among susceptible household contacts,

409 partners of the index case and those

410 with a BMI in the obesity range were at
Table 2. Potential risk factors for SARS-CoV-2 transmission from index cases

\begin{tabular}{|c|c|c|c|c|}
\hline INDEX CASES & $\begin{array}{c}\text { All Indexes } \\
(n, \%)\end{array}$ & $\begin{array}{c}\text { Transmitters } \\
\text { (n, \%) }\end{array}$ & $\begin{array}{c}\text { Non-transmitters } \\
(\mathrm{n}, \%)\end{array}$ & p-value \\
\hline & $92(100 \%)$ & $64(70 \%)$ & $28(30 \%)$ & - \\
\hline \multicolumn{5}{|c|}{ Age } \\
\hline$<18 y$ & $8(9 \%)$ & $5(8 \%)$ & $3(11 \%)$ & NS \\
\hline $18-50 y$ & $64(70 \%)$ & $44(69 \%)$ & $20(71 \%)$ & NS \\
\hline$>50 y$ & $20(22 \%)$ & $15(23 \%)$ & $5(18 \%)$ & NS \\
\hline \multicolumn{5}{|c|}{ Sex } \\
\hline Female & $49(53 \%)$ & $31(48 \%)$ & $18(64 \%)$ & NS \\
\hline Male & $43(47 \%)$ & $33(52 \%)$ & $10(36 \%)$ & - \\
\hline \multicolumn{5}{|c|}{ Mask wearing prior to enrollment (missing $n=4$ ) } \\
\hline Mask wearing at home & $15(17 \%)$ & $9(15 \%)$ & $6(22 \%)$ & NS \\
\hline \multicolumn{5}{|c|}{ Race/Ethnicity } \\
\hline White, non-Hispanic & $51(55 \%)$ & $30(47 \%)$ & $21(75 \%)$ & 0.02 \\
\hline Black or African American & $10(11 \%)$ & $8(13 \%)$ & $2(7 \%)$ & NS \\
\hline Other, non-Hispanic & $5(5 \%)$ & $5(8 \%)$ & $0(0 \%)$ & NS \\
\hline Hispanic/Latinx & $26(28 \%)$ & $21(33 \%)$ & $5(18 \%)$ & NS \\
\hline \multicolumn{5}{|c|}{ Symptom severity (missing $n=5$ ) } \\
\hline Mild & $25(29 \%)$ & $17(29 \%)$ & $8(29 \%)$ & NS \\
\hline Moderate/Severe & $58(67 \%)$ & $38(64 \%)$ & $20(71 \%)$ & NS \\
\hline Hospitalized & $4(5 \%)$ & $4(7 \%)$ & $0(0 \%)$ & NS \\
\hline \multicolumn{5}{|c|}{ Duration of symptoms at enrollment (missing $n=8$ ) } \\
\hline Median (IQR) & $6(4-7)$ & $6(5-7)$ & $6(4-7)$ & NS \\
\hline \multicolumn{5}{|c|}{ Antibody status at enrollment (missing $n=4$ ) } \\
\hline IgG-positive & $32(36 \%)$ & $24(39 \%)$ & $8(30 \%)$ & NS \\
\hline IgG-negative & $51(58 \%)$ & $34(56 \%)$ & $17(63 \%)$ & NS \\
\hline \multicolumn{5}{|c|}{ Co-morbidities for adults $>18 y$ (missing $n=1$ for diabetes, $n=5$ for obesity) } \\
\hline Diabetes & $6(7 \%)$ & $6(9 \%)$ & $0(0 \%)$ & NS \\
\hline Obesity, BMI >30 & $34(39 \%)$ & $26(43 \%)$ & $8(30 \%)$ & NS \\
\hline \multicolumn{5}{|c|}{ Education for adults $>18 y$ (missing $n=12$ ) } \\
\hline High school or lower & $36(45 \%)$ & $28(51 \%)$ & $8(32 \%)$ & NS \\
\hline College degree & $23(29 \%)$ & $15(27 \%)$ & $8(32 \%)$ & NS \\
\hline Graduate degree & $21(26 \%)$ & $12(22 \%)$ & $9(36 \%)$ & NS \\
\hline \multicolumn{5}{|c|}{ Occupation } \\
\hline Healthcare worker & $13(14 \%)$ & $5(8 \%)$ & $8(29 \%)$ & 0.01 \\
\hline
\end{tabular}

411 higher risk of acquiring infection (OR

412 4.1, 95\% Cl 1.3-13 and OR 5.4, 95\%

$413 \mathrm{Cl}$ 1.4-21, respectively) (Table 5).

414 While not reaching statistical

415 significance, non-white household

416 members and those who shared a

417 bedroom with the index case

418 appeared to have a higher risk of

419 infection. Sharing a bathroom was

420 associated with a higher risk of

421 secondary infection during study follow-up ( $p=0.01$, data not shown). Children of the index case had a lower risk of

422 infection, but this did not reach statistical significance (OR 0.42, 95\% Cl 0.15-1.2).
Table 3. Secondary attack rate by race/ethnicity of index case in the household

\begin{tabular}{|c|c|c|c|c|c|}
\hline \multirow{2}{*}{ Race/Ethnicity } & \multirow{2}{*}{$\begin{array}{c}\text { Susceptible } \\
\text { HCS }\end{array}$} & \multicolumn{3}{|c|}{ Secondary household transmission } & \multirow{2}{*}{ SAR $(95 \% \mathrm{Cl})$} \\
\hline & & at baseline & over 21 days & total* & \\
\hline All & 176 & 76 & 33 & $106 *$ & $60 \%(53-67 \%)$ \\
\hline White, non-Hispanic & 96 & 32 & 18 & 50 & $52 \%(42-62 \%)$ \\
\hline Non-white & 80 & 41 & 15 & 56 & $70 \%(59-79 \%)$ \\
\hline Black or African-American & 17 & 8 & 4 & 12 & $71 \%$ \\
\hline Hispanic/Latinx & 56 & 33 & 10 & $40^{*}$ & $71 \%$ \\
\hline Other, non-Hispanic & 7 & 3 & 1 & 4 & $57 \%$ \\
\hline
\end{tabular}

*accounting for 3 dropouts from secondary cases infected at baseline 
Table 4. Potential household-level risk factors for SARS-CoV-2 transmission

\begin{tabular}{|c|c|c|c|c|}
\hline HOUSEHOLDS & $\begin{array}{l}\text { All Households } \\
(n, \%)\end{array}$ & $\begin{array}{c}\text { Infected } \\
(n, \%)\end{array}$ & $\begin{array}{l}\text { Uninfected } \\
(n, \%)\end{array}$ & p-value \\
\hline & $92(100 \%)$ & $64(70 \%)$ & $28(30 \%)$ & - \\
\hline \multicolumn{5}{|c|}{ Household size } \\
\hline Mean & 3.8 & 3.9 & 3.4 & NS \\
\hline \multicolumn{5}{|c|}{ Living space (missing $n=5$ ) } \\
\hline$<2000 \mathrm{sqft}$ & $48(55 \%)$ & $37(62 \%)$ & $11(41 \%)$ & NS \\
\hline$>2000 \mathrm{sq} f \mathrm{ft}$ & $39(45 \%)$ & $23(38 \%)$ & $16(59 \%)$ & 0.07 \\
\hline \multicolumn{5}{|c|}{ Number of rooms* } \\
\hline 2 or fewer rooms & $10(11 \%)$ & $7(11 \%)$ & $3(11 \%)$ & NS \\
\hline 3-5 rooms & $40(43 \%)$ & $32(50 \%)$ & $8(29 \%)$ & NS \\
\hline 6 or more rooms & $42(46 \%)$ & $25(39 \%)$ & $17(61 \%)$ & NS \\
\hline \multicolumn{5}{|c|}{ Living density } \\
\hline$>3$ people and $<6$ rooms & $22(24 \%)$ & $20(31 \%)$ & $2(7 \%)$ & 0.02 \\
\hline \multicolumn{5}{|c|}{ Home ownership (missing $n=4$ ) } \\
\hline Renting apartment & $10(11 \%)$ & $8(13 \%)$ & $2(7 \%)$ & NS \\
\hline Renting home & $25(28 \%)$ & $19(32 \%)$ & $6(21 \%)$ & NS \\
\hline Own home & $53(60 \%)$ & $33(55 \%)$ & $20(71 \%)$ & NS \\
\hline
\end{tabular}

*Number of rooms includes bedrooms, kitchen, and common rooms, but not bathrooms or garage $p$-values only reported if $\leq 0.10$, otherwised noted as not significant (NS)
Table 5. Potential risk factors for SARS-CoV-2 infection among household contacts

\begin{tabular}{|c|c|c|c|c|}
\hline HOUSEHOLD CONTACTS & $\begin{array}{l}\text { All Household } \\
\text { Contacts (n, \%) }\end{array}$ & $\begin{array}{c}\text { Infected } \\
(\mathrm{n}, \%)\end{array}$ & $\begin{array}{c}\text { Uninfected } \\
(n, \%)\end{array}$ & p-value \\
\hline & $176(100 \%)$ & $109(62 \%)$ & $67(38 \%)$ & - \\
\hline \multicolumn{5}{|c|}{ Relationship to index case } \\
\hline Partner & $50(28 \%)$ & $37(34 \%)$ & $13(19 \%)$ & 0.02 \\
\hline Child & $61(35 \%)$ & 34 (31\%) & $27(40 \%)$ & 0.10 \\
\hline Parent & $27(15 \%)$ & $12(11 \%)$ & $15(22 \%)$ & NS \\
\hline Caregiver & $53(30 \%)$ & $31(28 \%)$ & $22(33 \%)$ & NS \\
\hline \multicolumn{5}{|c|}{ Age } \\
\hline$<18 y$ & $61(35 \%)$ & $35(32 \%)$ & $26(39 \%)$ & NS \\
\hline $18-50 y$ & $85(48 \%)$ & $55(50 \%)$ & $30(45 \%)$ & NS \\
\hline$>50 y$ & $30(17 \%)$ & $19(17 \%)$ & $11(16 \%)$ & NS \\
\hline \multicolumn{5}{|c|}{ Sex } \\
\hline Female & $89(51 \%)$ & $58(53 \%)$ & $31(46 \%)$ & NS \\
\hline Male & $87(49 \%)$ & $51(47 \%)$ & $36(54 \%)$ & - \\
\hline \multicolumn{5}{|c|}{ Shared activities prior to enrollment (missing $n=12$ ) } \\
\hline Sharing bedroom & $55(34 \%)$ & $38(38 \%)$ & $17(27 \%)$ & 0.10 \\
\hline Sharing bathroom & $105(64 \%)$ & 69 (69\%) & $36(56 \%)$ & NS \\
\hline Sharing meals & $112(68 \%)$ & $67(67 \%)$ & $45(70 \%)$ & NS \\
\hline Sharing car rides & $92(56 \%)$ & $57(57 \%)$ & $35(55 \%)$ & NS \\
\hline \multicolumn{5}{|c|}{ Mask wearing prior to enrollment (missing $n=21$ ) } \\
\hline Mask wearing at home & $40(26 \%)$ & $23(24 \%)$ & $17(29 \%)$ & NS \\
\hline \multicolumn{5}{|c|}{ Race/Ethnicity } \\
\hline White, non-Hispanic & $94(53 \%)$ & $50(46 \%)$ & $44(66 \%)$ & 0.06 \\
\hline Black or African American & $17(10 \%)$ & $12(11 \%)$ & $5(7 \%)$ & NS \\
\hline Other, non-Hispanic & $7(4 \%)$ & $4(4 \%)$ & $3(4 \%)$ & NS \\
\hline Hispanic/Latinx & $58(33 \%)$ & $43(39 \%)$ & $15(22 \%)$ & NS \\
\hline \multicolumn{5}{|c|}{ Co-morbidities for adults $>18 y$ (missing $n=19$ for diabetes, $n=31$ for obesity) } \\
\hline Diabetes & $9(8 \%)$ & $5(7 \%)$ & $4(10 \%)$ & NS \\
\hline Obesity, BMI >30 & $38(37 \%)$ & $31(48 \%)$ & $7(18 \%)$ & 0.02 \\
\hline \multicolumn{5}{|c|}{ Education for adults $>18 y$ (missing $n=22$ ) } \\
\hline High school or lower & $54(48 \%)$ & $40(56 \%)$ & $14(34 \%)$ & NS \\
\hline College degree & $33(29 \%)$ & $18(25 \%)$ & $15(37 \%)$ & NS \\
\hline Graduate degree & $25(22 \%)$ & $13(18 \%)$ & $12(29 \%)$ & NS \\
\hline
\end{tabular}

p-values are adjusted for household clustering and only reported if $\leq 0.10$

109 infected household contacts includes 3 that were already infected at baseline but dropped out after enrollment and thus not included in the SAR analysis.

67 uninfected includes the 70 in the SAR analysis but with an additional 3 excluded because

they did not have antibody testing at day 28 (though all were PCR-negative throughout the study) 
medRxiv preprint doi: https://doi.org/10.1101/2021.03.10.21253173; this version posted March 12, 2021. The copyright holder for this preprint (which was not certified by peer review) is the author/funder, who has granted medRxiv a license to display the preprint in perpetuity. It is made available under a CC-BY-NC-ND 4.0 International license .

423 DISCUSSION

424 Household transmission is one of the main drivers of the SARS-CoV-2 pandemic. By incorporating timely 425 recruitment of index cases, prospective sampling to 21 days regardless of symptom status, and diverse 426 representation, we show that household transmission occurs in the majority of COVID-positive North Carolina 427 households. The overall secondary attack rate in our sample was $60 \%$, rising to $70 \%$ in minority households and $42891 \%$ in households with higher living density. Importantly, we show not only that those infected with a high viral 429 load are more likely to transmit virus to other members of the household, but that they seed other high-viral load 430 infections, putting the entire household at higher risk for more severe illness [21]. Spread within the household 431 happens quickly, often with one or more household members already infected by the time the first case in the 432 household is diagnosed.

433 While the most complete meta-analysis of household transmission studies, published in December 2020, found a 434 much lower overall household SAR of $16.6 \%$ (95\% Cl, 14.0\%-19.3\%), it noted significant heterogeneity between 435 studies (ranging 4-45\%) and combined both retrospective studies based on contact tracing data and prospective 436 analyses, with the former comprising most of the studies [6]. As would be expected, studies with increased 437 frequency of testing regardless of symptom status generally show higher infection rates [22]. In the US, a 438 retrospective study in New York that included household testing offered regardless of symptom status reported a 439 SAR of 38\% [23], while two more recently published prospective studies following a total of 159 households in Utah 440 and Wisconsin (58 households, SAR 29\%)[7], and Tennessee and Wisconsin (101 households, SAR 53\%) [8] also 441 report higher SARs. The former study was completed during a time of shelter-in-place policies. A retrospective 442 study of 32 households of pediatric cases that relied on symptom ascertainment, also during a time of 443 shelter-in-place, found a SAR of $46 \%$ [24]. Altogether, these studies have started to paint a picture of much higher 444 secondary attack rates within households.

445 There are several likely explanations for why the SAR we report is the highest yet among US studies. Compared to 446 previous studies, this study had longer follow-up, including weekly PCR testing to 21 days, combined with antibody 447 testing at day 28. Longer follow-up is needed to capture potential tertiary cases (from sequential transmission) in 448 the household. However, cases identified later during follow-up may also have been acquired in the community, as 449 the study spanned seven months whilst the epidemic in North Carolina evolved from nursing homes, prisons, and 450 meatpacking facilities; to frontline workers; to returning college students; and finally the general population. We 451 suspect separately community-acquired cases are few amongst the household contacts in this study, but even 452 limiting our SAR analysis to secondary cases detected within the first week of enrollment, the attack rate among 453 household contacts is still $>50 \%$. Second, representation of racial and ethnic diversity has been limited in prior 454 studies (>=70\% white, non-Hispanic in each of the three aforementioned studies $[7,8,23]$ ). We found that risk 455 factors for secondary infection in household contacts - including higher living density and obesity - were more 456 frequent among households with participants who identified as non-white or Hispanic, who comprised $45 \%$ of our 457 study sample. Third, although we excluded $22 \%$ of household contacts infected at baseline due to report of a 458 common exposure as the index case, this proportion may in fact have been higher due to potential recall bias for 459 common exposures. However, in our experience, a large proportion of these exposures still occur among family, if 460 not the immediate household. In $44 \%$ of households, at least one household member (most often young children) 461 declined to participate, which may have biased our estimate as well. Finally, the CO-HOST study was conducted 462 during a time when the potentially more infectious 614G variant [25] predominated in North Carolina, involving $463>95 \%$ of our sample, paralleling its rise and dominance in the United States [18]. Overall, it is clear that SAR will vary 
medRxiv preprint doi: https://doi.org/10.1101/2021.03.10.21253173; this version posted March 12, 2021. The copyright holder for this preprint (which was not certified by peer review) is the author/funder, who has granted medRxiv a license to display the preprint in perpetuity.

It is made available under a CC-BY-NC-ND 4.0 International license .

464 in different settings and needs to be contextualized based on geography, risk groups, and the level of community 465 transmission and public policies in effect at the time of the study.

466 Our data, with the majority of cases occurring within one week from illness onset in the index case, are consistent 467 with previous modeling studies indicating that infectiousness peaks just before the onset of symptoms [3-5,26]. 468 Practically speaking, this means that by the time the first case in the household is diagnosed, others are already 469 incubating virus if not already testing positive. This is especially true when there are delays to testing or obtaining 470 results, as was common in the first few months of the pandemic. Thus, public health messages to wear masks and 471 self-isolate at onset of symptoms, while prudent, are unlikely to eliminate household spread, even if they were 472 feasible in all households. Early and frequent testing, combined with agents for post-exposure prophylaxis, would 473 be needed to substantially mitigate the impact of the virus on families that have been inoculated and not yet 474 vaccinated [27]. Otherwise, mask wearing within a household at all times is preferable in households with 475 unvaccinated members who are vulnerable to severe COVID-19.

476 The length of household quarantine is often problematic for COVID-positive persons and their households. Current 477 recommendations worldwide favor a 14-day quarantine period for the entire household if one member is infected. 478 However, compliance is difficult, especially for families with young children, those with limited resources, and those 479 unable to work from home. If the quarantine period is decreased, the risk of onward transmission is increased, but 480 the size of this risk remains an active subject of investigation [20,27]. One approach has been to reset the 481 'quarantine clock' for the entire household by 14 days each time a new household member is diagnosed, but this 482 has further increased the burden and decreased compliance. In this study, two-thirds of household contacts were 483 already infected at enrollment, a median of 6 days after symptom onset in the index case. We found that $94 \%$ of 484 secondary cases were detected within 14 days from symptom onset of the index case, and resetting the clock on 485 quarantine based on subsequent cases in the household was of incremental benefit (capturing an additional $4 \%$ of 486 cases). This data supports the recommendation of a single 14-day quarantine for the entire household.

487 A novel finding of our study is the correlation of SARS-CoV-2 viral burden within households. Increased viral load 488 increases infectivity in vivo [25], and a recent study of 282 clusters in Spain (many involving household contacts) 489 showed increased risk of transmission with shorter time to onset of symptoms among contacts as viral load 490 increased [28]. Additionally, an increasing number of studies are confirming that greater viral burden (high viral load 491 or lower Ct values by PCR) is associated with disease severity $[21,29,30]$. Now adding a third piece to this puzzle, we 492 show that households seeded with a high viral load infection are more likely to have others with high viral loads, 493 and therefore increased risk for severe illness. This implies that when a person is hospitalized, others in the same 494 household may be at an even higher risk for a similar outcome compared to risk based on their individual risk 495 factors (age, comorbidities) alone. Anecdotally, husbands and wives, siblings, and adult parents and children are not 496 infrequently hospitalized in succession, though the prevalence of this is unknown. An inoculum effect may underlie 497 this finding [31] and also explain why secondary cases in households appear to be overdispersed, with either most 498 or all members infected, or none at all $[6,32,33]$. Viral load dynamics will no doubt continue to shape household 499 transmission and the larger pandemic, as newer, potentially more infectious variants emerge even as vaccination 500 decreases the "community viral load."

501 To our knowledge, this is also the first study to show increased transmission in non-white US households. Though 502 they experience similar rates of case fatality, African American/Black and Hispanic populations in the US experience 503 disproportionately higher rates of SARS-CoV-2 infection and COVID-19-related mortality [34]. These racial 504 disparities are thought to be due to differences in health care access and exposure risk that are driven by systemic 505 societal inequities rather than individual biological or behavioral characteristics [35-38]. The CO-HOST study is 
medRxiv preprint doi: https://doi.org/10.1101/2021.03.10.21253173; this version posted March 12, 2021. The copyright holder for this preprint (which was not certified by peer review) is the author/funder, who has granted medRxiv a license to display the preprint in perpetuity.

It is made available under a CC-BY-NC-ND 4.0 International license .

506 consistent with this explanation. While the sample size was not sufficient to investigate drivers of the increased

507 transmission in minority households, we found that high living density/household crowding, which was more

508 common in the non-white households, was associated with increased transmission. Trends in home ownership,

509 educational status, and living space within our data support the role of social vulnerabilities in modulating

510 transmission risk within households, a major setting of SARS-CoV-2 transmission.

511 In our risk factors analysis, we found that spouses/partners and household members with obesity were at higher 512 risk of becoming infected, while households of healthcare workers were less likely to become infected. All of the 513 index cases in this study were symptomatic, hence we were unable to assess the likelihood of transmission from 514 symptomatic versus asymptomatic cases. We were also unable to detect any impact of age or other comorbidities 515 on acquisition of infection, likely due to the small effect size mediated through these variables and limited sample 516 numbers. However, a meta-analysis has found that secondary attack rates are increased from symptomatic index 517 cases in comparison to asymptomatic cases, adult index cases in comparison to child index cases, and in spouses 518 compared to other family members [6].

519 In conclusion, SARS-CoV-2 transmits early and often among household members. While masking, physical 520 distancing, and quarantining the whole household may reduce or prevent transmission beyond the household, 521 these strategies are less effective and feasible within the household, especially in the setting of high viral load 522 infections and crowded living spaces. Frequent point-of-care testing and prophylaxis in those at-risk for severe 523 illness, and ultimately widespread and equitable distribution of vaccines, are needed to lessen the impact of 524 COVID-19 within households and vulnerable communities.

\section{DATA AVAILABILITY}

526 Data is available on request for any interested researchers to allow replication of results provided all ethical 527 requirements are met.

\section{ACKNOWLEDGEMENTS}

529 We thank our wonderful CO-HOST study participants, Moby and the Chapel Hill CRS, and the UNC RDC team. 530 Thanks to Mlchelle Berrey, JoAnn Kuruc, and Dania Munson for help with protocol writing and submission; to 531 Oksana Kharabora, Maureen Furlong, Amy James Loftis, Tia Belvin, and Dana Swilley for help with study preparation 532 and implementation; to Joe Eron, Billy Fischer, and Ada Adimora for their input and support; and to Gabby Streeter 533 for help with data analysis.

\section{FUNDING}

535 Research was supported by funds and charitable contributions from the UNC Department of Medicine, UNC 536 COVID-19 Response Fund/Health Foundation, a Gillings Innovations Lab Award, and the National Center for 537 Advancing Translational Sciences (NCATS), National Institutes of Health, through Grant Award Number 538 UL1TR002489. Rapid antibody tests were provided by Biomedomics Inc, Morrisville, NC. 
medRxiv preprint doi: https://doi.org/10.1101/2021.03.10.21253173; this version posted March 12, 2021. The copyright holder for this preprint (which was not certified by peer review) is the author/funder, who has granted medRxiv a license to display the preprint in perpetuity.

It is made available under a CC-BY-NC-ND 4.0 International license .

\section{SUPPORTING INFORMATION}

\section{Figure S1. Schematic of CO-HOST Study Design}

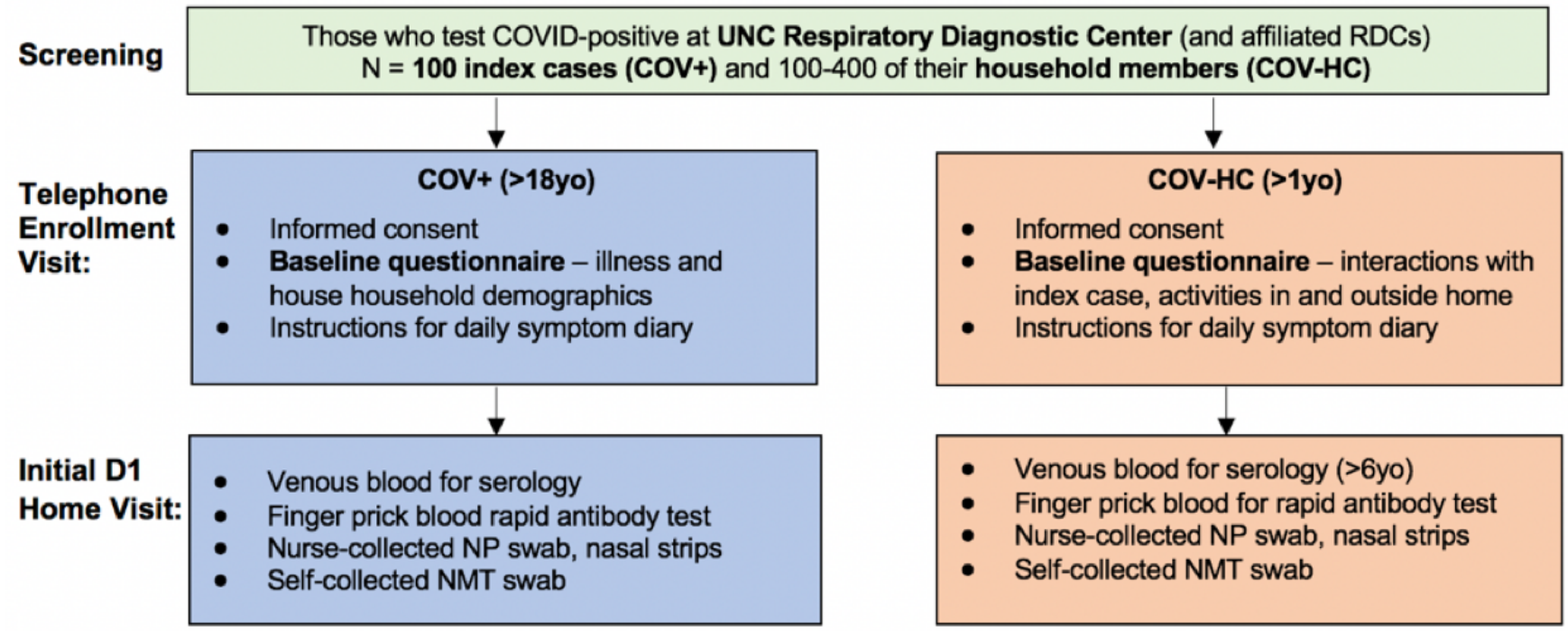

Follow up: Serial swabs to measure viral clearance and viral shedding

Week 1:

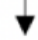

\section{D7 visit: Self-collected NMT swab}

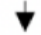

Week 2:

D14 visit: Self-collected NMT.swab

Week 3:

D21 visit: Self-collected NMT swab

$\downarrow$

Final D28

RDC visit:

- Venous blood for serology

- $\quad$ Finger prick blood rapid antibody test
Serial swabs to detect new COVID-19 infection

\begin{tabular}{|c|}
\hline Daily \\
symptom \\
diary \\
(electronic) \\
Until sx \\
resolution $x$ \\
2 days \\
(COV+) \\
\\
D1-D21 \\
(COV-HC) \\
\end{tabular}

D7 visit: Self-collected NMT swab

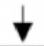

D14 visit: Self-collected NMT swab

- Interim questionnaire

D21 visit: Self-collected NMT swab

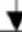

- Venous blood for serology

- Finger prick blood rapid antibody test

Table S1: Sequences of primers, probes, and plasmids used for SARS-CoV-2 D614G genotyping by real-time PCR

\begin{tabular}{|c|c|}
\hline Reagent & Sequence $\left(5^{\prime} \rightarrow 3^{\prime}\right)$ \\
\hline Forward Primer & TTCTTTTGGTGGTGTCAGTGTTATAAC \\
\hline Reverse Primer & CATGAATAGCAACAGGGACTTCTG \\
\hline Wild-type Probe & FAM-TCTTTATCAGGATGTTAAC-MGB \\
\hline Mutant Probe & VIC-TTCTTTATCAGGGTGTTAAC-MGB \\
\hline \multirow{2}{*}{$\begin{array}{l}\text { Wild-type Plasmid } \\
\text { Insert }\end{array}$} & TTACACCATGTTCTTTTGGTGGTGTCAGTGTTATAACACCAGGAACA \\
\hline & AATACTTCTAACCAGGTTGCTGTTCTTTATCAGGATGTTAACTGCA \\
\hline \multirow{3}{*}{$\begin{array}{l}\text { Mutant Plasmid } \\
\text { Insert }\end{array}$} & TTACACCATGTTCTTTTGGTGGTGTCAGTGTTATAACACCAGGAACA \\
\hline & 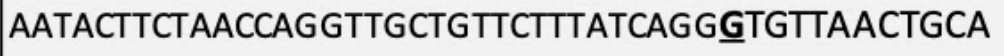 \\
\hline & CAGAAGTCCCTGTTGCTATTCATGCAGATCAACTTAC \\
\hline
\end{tabular}


medRxiv preprint doi: https://doi.org/10.1101/2021.03.10.21253173; this version posted March 12, 2021. The copyright holder for this preprint (which was not certified by peer review) is the author/funder, who has granted medRxiv a license to display the preprint in perpetuity.

Table S2. Comorbidities of study participants

\begin{tabular}{|c|c|c|c|c|}
\hline INDIVIDUALS & Index (n) & Index (\%) & $\mathrm{HC}(\mathrm{n})$ & HC (\%) \\
\hline Underlying Conditions for Adults >18y* & 92 & $\%$ & 134 & $\%$ \\
\hline Cancer & 3 & 3.3 & 0 & 0.0 \\
\hline Chronic lung disease & 1 & 1.1 & 2 & 1.5 \\
\hline Asthma & 9 & 9.8 & 19 & 14.2 \\
\hline Daily smoker & 2 & 2.2 & 11 & 8.2 \\
\hline Diabetes & 6 & 6.5 & 12 & 9.0 \\
\hline High blood pressure & 16 & 17.4 & 30 & 22.4 \\
\hline Heart disease & 2 & 2.2 & 2 & 1.5 \\
\hline Chronic kidney disease & 1 & 1.1 & 0 & 0.0 \\
\hline Recent (within past 2 weeks) or current pregnancy & 3 & 3.3 & 5 & 3.7 \\
\hline BMI >30 & 35 & 38.0 & 43 & 32.1 \\
\hline BMI 25-29.9 & 24 & 26.1 & 37 & 27.6 \\
\hline Underlying Conditions for Adults >50y* & 23 & $\%$ & 42 & $\%$ \\
\hline Asthma & 2 & 8.7 & 2 & 4.8 \\
\hline Daily smoker & 0 & 0.0 & 5 & 11.9 \\
\hline Diabetes & 5 & 21.7 & 7 & 16.7 \\
\hline High blood pressure & 6 & 26.1 & 21 & 50.0 \\
\hline BMI >30 & 11 & 47.8 & 14 & 33.3 \\
\hline BMI 25-29.9 & 5 & 21.7 & 16 & 38.1 \\
\hline BMI >30 and one or more co-morbidity (adults $>18 y)(n=92,134)$ & 22 & 23.9 & 25 & 18.7 \\
\hline BMI $>30$ and one or more co-morbidity (adults $>50 y)(n=23,42)$ & 8 & 34.8 & 12 & 28.6 \\
\hline${ }^{*}$ No adults $>18 y$ with HIV or chronic liver disease & & & & \\
\hline
\end{tabular}

Table S3. Household demographics

\begin{tabular}{|c|c|c|}
\hline HOUSEHOLDS & $(n=100)$ & (\%) \\
\hline \multicolumn{3}{|l|}{ Household Size } \\
\hline 2 People & 27 & 27.0 \\
\hline 3 People & 23 & 23.0 \\
\hline 4 People & 22 & 22.0 \\
\hline 5 or more people & 28 & 28.0 \\
\hline \multicolumn{3}{|l|}{ Home Ownership ( $n=97)$} \\
\hline Single-family home/townhome occupied by owner & 61 & 62.9 \\
\hline Single-family home/townhome occupied by renter & 25 & 25.8 \\
\hline Apartment occupied by renter & 10 & 10.3 \\
\hline Other & 1 & 1.0 \\
\hline \multicolumn{3}{|l|}{ Rooms in the House* } \\
\hline 2 or fewer rooms & 10 & 10.0 \\
\hline 3-5 rooms & 43 & 43.0 \\
\hline $\begin{array}{l}6 \text { or more rooms } \\
\text { *including bedrooms, kitchen, and common rooms, } \\
\text { but not bathrooms or garage }\end{array}$ & 47 & 47.0 \\
\hline \multicolumn{3}{|l|}{ Living Space } \\
\hline$<500 \mathrm{sq}$ feet $(<46.5 \mathrm{sq} \mathrm{m})$ & 3 & 3.0 \\
\hline $500-1000$ sq feet (46-93 sq m) & 17 & 17.0 \\
\hline $1000-2000$ sq feet (93-186 sq m) & 33 & 33.0 \\
\hline$>2000$ sq feet (>186 sq m) & 42 & 42.0 \\
\hline Unknown & 5 & 5.0 \\
\hline
\end{tabular}


medRxiv preprint doi: https://doi.org/10.1101/2021.03.10.21253173; this version posted March 12, 2021. The copyright holder for this preprint (which was not certified by peer review) is the author/funder, who has granted medRxiv a license to display the preprint in perpetuity. It is made available under a CC-BY-NC-ND 4.0 International license .

\section{REFERENCES}

1. Meyerowitz EA, Richterman A, Gandhi RT, Sax PE. Transmission of SARS-CoV-2: A Review of Viral, Host, and Environmental Factors. Ann Intern Med. 2021;174: 69-79.

2. CDC. Public Health Guidance for Community-Related Exposure. 3 Dec 2020 [cited 16 Feb 2021]. Available: https://www.cdc.gov/coronavirus/2019-ncov/php/public-health-recommendations.html

3. He X, Lau EHY, Wu P, Deng X, Wang J, Hao X, et al. Temporal dynamics in viral shedding and transmissibility of COVID-19. Nat Med. 2020;26: 672-675.

4. Tindale LC, Stockdale JE, Coombe M, Garlock ES, Lau WYV, Saraswat M, et al. Evidence for transmission of COVID-19 prior to symptom onset. Elife. 2020;9. doi:10.7554/eLife.57149

5. Benefield AE, Skrip LA, Clement A, Althouse RA, Chang S, Althouse BM. SARS-CoV-2 viral load peaks prior to symptom onset: a systematic review and individual-pooled analysis of coronavirus viral load from 66 studies. bioRxiv. medRxiv; 2020. doi:10.1101/2020.09.28.20202028

6. Madewell ZJ, Yang Y, Longini IM Jr, Halloran ME, Dean NE. Household Transmission of SARS-CoV-2: A Systematic Review and Meta-analysis. JAMA Netw Open. 2020;3: e2031756.

7. Lewis NM, Chu VT, Ye D, Conners EE, Gharpure R, Laws RL, et al. Household Transmission of SARS-CoV-2 in the United States. Clin Infect Dis. 2020. doi:10.1093/cid/ciaa1166

8. Grijalva CG, Rolfes MA, Zhu Y, McLean HQ, Hanson KE, Belongia EA, et al. Transmission of SARS-COV-2 Infections in Households - Tennessee and Wisconsin, April-September 2020. MMWR Morb Mortal Wkly Rep. 2020;69: 1631-1634.

9. McNamara RP, Caro-Vegas C, Landis JT, Moorad R, Pluta LJ, Eason AB, et al. High-Density Amplicon Sequencing Identifies Community Spread and Ongoing Evolution of SARS-CoV-2 in the Southern United States. Cell Rep. 2020;33: 108352.

10. Barzin A, Wohl DA, Daaleman TP. Development and Implementation of a COVID-19 Respiratory Diagnostic Center. Ann Fam Med. 2020;18: 464.

11. for Disease Control C, Prevention, Others. CDC 2019-novel coronavirus (2019-nCoV) real-time RT-PCR diagnostic panel. Revis Biol Celular. 2020;3: 30.

12. Muller MS, Bhattarai Chhetri S, Basham C, Rapp T, Lin F-C, Lin K, et al. Practical strategies for SARS-CoV-2 RT-PCR testing in resource-constrained settings. medRxiv; 2021. doi:10.1101/2021.02.18.21251999

13. Li Z, Yi Y, Luo X, Xiong N, Liu Y, Li S, et al. Development and clinical application of a rapid IgM-IgG combined antibody test for SARS-CoV-2 infection diagnosis. J Med Virol. 2020;92: 1518-1524.

14. COVID-19 IgM/IgG Rapid Test - BioMedomics Inc. [cited 17 Feb 2021]. Available: https://www.biomedomics.com/products/infectious-disease/covid-19-rt/

15. Naranbhai V, Chang CC, Beltran WFG, Miller TE, Astudillo MG, Villalba JA, et al. High Seroprevalence of Anti-SARS-CoV-2 Antibodies in Chelsea, Massachusetts. J Infect Dis. 2020;222: 1955-1959.

16. Premkumar L, Segovia-Chumbez B, Jadi R, Martinez DR, Raut R, Markmann A, et al. The receptor binding domain of the viral spike protein is an immunodominant and highly specific target of antibodies in SARS-CoV-2 patients. Sci Immunol. 2020;5. doi:10.1126/sciimmunol.abc8413

17. Markmann AJ, Giallourou N, Bhowmik DR, Hou YJ, Lerner A, Martinez DR, et al. Sex disparities and neutralizing antibody durability to SARS-CoV-2 infection in convalescent individuals. medRxiv. 2021. doi:10.1101/2021.02.01.21250493 
medRxiv preprint doi: https://doi.org/10.1101/2021.03.10.21253173; this version posted March 12, 2021. The copyright holder for this preprint (which was not certified by peer review) is the author/funder, who has granted medRxiv a license to display the preprint in perpetuity. It is made available under a CC-BY-NC-ND 4.0 International license .

18. Korber B, Fischer WM, Gnanakaran S, Yoon H, Theiler J, Abfalterer W, et al. Tracking Changes in SARS-CoV-2 Spike: Evidence that D614G Increases Infectivity of the COVID-19 Virus. Cell. 2020;182: 812-827.e19.

19. Explore Obesity in North Carolina. [cited 23 Feb 2021]. Available: https://www.americashealthrankings.org/explore/annual/measure/Obesity/state/NC

20. Rolfes MA, Grijalva CG, Zhu Y, McLean HQ, Hanson KE, Belongia EA, et al. Implications of Shortened Quarantine Among Household Contacts of Index Patients with Confirmed SARS-CoV-2 Infection - Tennessee and Wisconsin, April-September 2020. MMWR Morb Mortal Wkly Rep. 2021;69: 1633-1637.

21. Maltezou HC, Raftopoulos V, Vorou R, Papadima K, Mellou K, Spanakis N, et al. Association between upper respiratory tract viral load, comorbidities, disease severity and outcome of patients with SARS-CoV-2 infection. J Infect Dis. 2021. doi:10.1093/infdis/jiaa804

22. Fung HF, Martinez L, Alarid-Escudero F, Salomon JA, Studdert DM, Andrews JR, et al. The Household Secondary Attack Rate of Severe Acute Respiratory Syndrome Coronavirus 2 (SARS-CoV-2): A Rapid Review. Clin Infect Dis. 2020 [cited 21 Feb 2021]. doi:10.1093/cid/ciaa1558

23. Rosenberg ES, Dufort EM, Blog DS, Hall EW, Hoefer D, Backenson BP, et al. COVID-19 Testing, Epidemic Features, Hospital Outcomes, and Household Prevalence, New York State-March 2020. Clin Infect Dis. 2020 [cited 13 Sep 2020]. doi:10.1093/cid/ciaa549

24. Teherani MF, Kao CM, Camacho-Gonzalez A, Banskota S, Shane AL, Linam WM, et al. Burden of Illness in Households With Severe Acute Respiratory Syndrome Coronavirus 2-Infected Children. J Pediatric Infect Dis Soc. 2020;9: 613-616.

25. Hou YJ, Chiba S, Halfmann P, Ehre C, Kuroda M, Dinnon KH 3rd, et al. SARS-CoV-2 D614G variant exhibits efficient replication ex vivo and transmission in vivo. Science. 2020;370: 1464-1468.

26. Cevik M, Tate M, Lloyd O, Maraolo AE, Schafers J, Ho A. SARS-CoV-2, SARS-CoV, and MERS-CoV viral load dynamics, duration of viral shedding, and infectiousness: a systematic review and meta-analysis. Lancet Microbe. 2021;2: e13-e22.

27. Quilty BJ, Clifford S, Hellewell J, Russell TW, Kucharski AJ, Flasche S, et al. Quarantine and testing strategies in contact tracing for SARS-CoV-2: a modelling study. Lancet Public Health. 2021. doi:10.1016/S2468-2667(20)30308-X

28. Marks M, Millat-Martinez P, Ouchi D, Roberts $\mathrm{CH}$, Alemany A, Corbacho-Monné $\mathrm{M}$, et al. Transmission of COVID-19 in 282 clusters in Catalonia, Spain: a cohort study. Lancet Infect Dis. 2021. doi:10.1016/S1473-3099(20)30985-3

29. Magleby R, Westblade LF, Trzebucki A, Simon MS, Rajan M, Park J, et al. Impact of SARS-CoV-2 Viral Load on Risk of Intubation and Mortality Among Hospitalized Patients with Coronavirus Disease 2019. Clin Infect Dis. 2020. doi:10.1093/cid/ciaa851

30. Liu Y, Yan L-M, Wan L, Xiang T-X, Le A, Liu J-M, et al. Viral dynamics in mild and severe cases of COVID-19. Lancet Infect Dis. 2020;20: 656-657.

31. Silvia Munoz-Price L, Rivera F, Ledeboer N. Air contamination of households versus hospital inpatient rooms occupied by SARS-CoV-2 positive patients. Infect Control Hosp Epidemiol. : 1-14.

32. Ladhani SN, Andrews N, Aiano F, Baawuah F, Amin-Chowdhury Z, Brown KE, et al. Secondary attack rate and family clustering of SARS-CoV-2 infection in children of healthcare workers with confirmed COVID-19. Clin Infect Dis. 2020. doi:10.1093/cid/ciaa1737

33. Tibebu S, Brown KA, Daneman N, Paul LA, Buchan SA. Household secondary attack rate of COVID-19 by 
medRxiv preprint doi: https://doi.org/10.1101/2021.03.10.21253173; this version posted March 12, 2021. The copyright holder for this preprint (which was not certified by peer review) is the author/funder, who has granted medRxiv a license to display the preprint in perpetuity. It is made available under a CC-BY-NC-ND 4.0 International license .

household size and index case characteristics. medRxiv. 2021. Available:

34. Mackey K, Ayers CK, Kondo KK, Saha S, Advani SM, Young S, et al. Racial and Ethnic Disparities in COVID-19-Related Infections, Hospitalizations, and Deaths : A Systematic Review. Ann Intern Med. 2020. doi:10.7326/M20-6306

35. Karmakar M, Lantz PM, Tipirneni R. Association of Social and Demographic Factors With COVID-19 Incidence and Death Rates in the US. JAMA Netw Open. 2021;4: e2036462.

36. Poteat T, Millett GA, Nelson LE, Beyrer C. Understanding COVID-19 risks and vulnerabilities among black communities in America: the lethal force of syndemics. Ann Epidemiol. 2020;47: 1-3.

37. Holmes L, Enwere M, Williams J, Ogundele B, Chavan P, Piccoli T, et al. Black--White risk differentials in COVID-19 (SARS-COV2) transmission, mortality and case fatality in the United States: translational epidemiologic perspective and challenges. Int J Environ Res Public Health. 2020;17: 4322.

38. Rogers TN, Rogers CR, VanSant-Webb E, Gu LY, Yan B, Qeadan F. Racial Disparities in COVID-19 Mortality Among Essential Workers in the United States. World medical \& health policy. 2020;12: 311-327. 